Journal of Advanced Research in Fluid Mechanics and Thermal Sciences

Journal homepage: www.akademiabaru.com/arfmts.html ISSN: 2289-7879

\title{
Numerical Investigation of The Air Flow Rate Effect Performance of Earth to Air Heat Exchanger Used for Cooling of Poultry Houses
}

\author{
Mushtaq I. Hasan ${ }^{1}$, Dhay Mohammed Muter ${ }^{1, *}$ \\ 1 Mechanical Engineering Department, College of Engineering, Thi-Qar University, Iraq
}

\section{ARTICLE INFO}

\section{Article history:}

Received 25 February 2021

Received in revised form 25 April 2021

Accepted 29 April 2021

Available online 26 July 2021

\section{Keywords:}

Numerical investigation; earth to air heat exchanger; poultry houses; overall performance factor

\section{ABSTRACT}

Usually, poultry houses are located in a remote area where there is no electricity, and where there is electricity, it is expensive, so resorting to these solutions is considered important solutions to save electrical energy and provide free cooling. The main part of generated energy is consumed by cooling and heating systems. One of the wellknown approaches to implemented heating and cooling system is earth to air heat exchanger (EAHE) system. This system is effective passive heating and cooling systems which can be used with poultry houses and building. This research studies numerically the effect of mass flow rate on the overall performance of earth to air HE for poultry houses. Four parameters (mass flow rate, required rate, required cooling load and pipe lengths) are selected under environment of Nasiriyah city (a city located in the south of Iraq). The study is conducted using PVC material. The study has been done during summer season. The suggested numerical model has been tested and validated using existing approaches selected from literature review papers. This test shows good agreement with results of selected papers. Moreover, validation and simulation results showed that the required cooling load increased with increasing mass flow rate. Also, with the increasing length of pipe of EAHE, the inflow temperature compared to the space temperature is decreased. However, the overall performance factor of EAHEs decreases by the increase of length of pipe and mass flow rate. Which indicate the possibility of using the earth to air heat exchanger for cooling and heating poultry houses and reduce the use of electrical energy.

\section{Introduction}

Earth-to-air heat exchanger is a passive heating and cooling systems and is used in wide types of applications for example heating and cooling greenhouse, industrial and inhabitation buildings. EAHE is usually involved of pipe or more pipes inside the earth vertically or horizontally. First, the end of the pipe is linked by the supply end of the fan and the addition of the side is open for air. While the air flows during the burned of pipes, the heat is transformed from air to the contiguous soil through a summer period and in the opposite in the winter season. Some researchers have shown the earth-

\footnotetext{
* Corresponding author.

E-mail address: dhaydhaymm@gmail.com
}

https://doi.org/10.37934/arfmts.84.2.167184 
to air heat exchangers (EAHE) coupled by buildings like an operative passive energy source to the heating and cooling systems.

Sodha et al., [1] investigated the earth air heat exchanger pipe length requisite in the cooling of the model with different earth surface dealings of Delhi (India) for the compound climate. They observed from the results that for meeting the cooling load requirements the dry sunny surface requisite a long tunnel, while, wet shaded superficial requisite the shortest one. From the model of their study, they saw that improvement of the temperature of the profiles in soil with great moisture of contents is faster than compared to the soil with little moisture contents.

Sharan and Jadhav [2] used earth air heat exchanger system to the heating and cooling with modes was working in India, Ahmedabad, with yearly the average temperature varieties between $\left(23^{\circ} \mathrm{C}\right.$ and $\left.43^{\circ} \mathrm{C}\right)$. The EAHE system contained a nominal diameter of $0.10 \mathrm{~m}$ with a $50 \mathrm{~m}$ length pipe, and depth of burial and thickness of $3 \mathrm{~m}$ and $0.003 \mathrm{~m}$, respectively. $11 \mathrm{~m} / \mathrm{s}$ is a velocity used of the air was pushed through the pipe with a $400 \mathrm{~W}$ electro-pump. cooling and Heating trials were performed through the three following days in May and January respectively. The temperatures were recorded at the entrance, middle, and end of the pipe. They found that the system was capable to rise the temperature by nearly $14^{\circ} \mathrm{C}$ in January and reduction the temperature in May with the same value. The performance coefficient (COP) for heating and cooling was 3.8 and 3.3, respectively.

Al-Ajmi et al., [3] advanced the theoretical model to calculate an earth air heat exchanger temperature of air outlet and the potential of this the cooling apparatus in a dry and hot climate. The model for a typical home of Kuwait City, in TRNSYS-IISIBAT environment was coded. They found that the EAHE system had the ability to decrease home cooling energy request through the summer season by $30 \%$.

Okonkwo and Akubuo [4] have conducted an experimentally investigation the poultry house, with solar Trombe wall which is equipped in order to the provide the ventilation, cooling and heating to a poultry house. They noted that the system maintained on the temperature in the range of $28^{\circ} \mathrm{C}$ to $35^{\circ} \mathrm{C}, 586$ is grams the average body weight, the rate of mortality is around $3 \%$ and the feed conversion ratio is $1.87 \%$.

Ahachad et al., [5] studied experimentally the influence of the phenomenon of heat stress are offered with simulating and modeling on the poultry house and it the influence of all parameter on the performance of the building (shape, ventilation, orientation etc.) in North of Morocco. The poultry house operated by passive cooling systems. $10 \mathrm{~m}$ in length and $4 \mathrm{~m}$ in height for the east and west walls with the total window opening of $3 \mathrm{~m}^{2}$ on every wall and $50 \mathrm{~m}$ in the length and $4 \mathrm{~m}$ in height for the north and south walls with a complete window opening of $16.5 \mathrm{~m}^{2}$ on each wall, and from the results showed temperature will decrease per 2 air changes per hour by about $1.5^{\circ} \mathrm{C}$, for 5 air changes per hour to $2.7^{\circ} \mathrm{C}$ and for 10 air variations per hour $3.8^{\circ} \mathrm{C}$ the temperature of the inlet air reduction (up to $9^{\circ} \mathrm{C}$ ), and the production quality is enhancement. the ventilation led to a maximum decrease of cycle cooling capacity of $29.9 \%$.

Ghosal et al., [6] advanced numerical model of using the stored thermal energy of ground for space heating to investigate the potential with the advantage of (EAHE) system with the greenhouse situated in the Delhi, India. Experimental, the diameter and the length of buried pipes used were 0.06 $\mathrm{m}$ and $39 \mathrm{~m}$ correspondingly. Also, EAHE included the depth of $1 \mathrm{~m}$ of PVC pipes buried below ground surface. The temperatures of air were discovered to be on an average $7^{\circ} \mathrm{C}$ to $8^{\circ} \mathrm{C}$ greater than the same greenhouse when operational without EAHE.

Che and Tiwari [7] executed an experimental during winter season thermal analysis with earthair heat exchanger (EAHE) system for a building integrated. The dimensions of building air temperature showed that with using EAHE system is an increase by $5^{\circ} \mathrm{C}$ to $15.8^{\circ} \mathrm{C}$ in the air temperature of building compared with ambient air temperature, while the temperature of building 
air decreases with the same period through summer season; consequently, the concluded that the EAHE is appropriate to an axillary system for heating and cooling buildings.

Bansal et al., [8] numerical study carried out on the earth air thermal heat exchanger system through the winter season. From their results they proved that $23.4 \mathrm{~m}$ of long the earth air thermal heat exchanger system can increase the air of temperature for the flow of velocities of ( 2 to $5 \mathrm{~m} / \mathrm{s}$ ) in the range from $4.1^{\circ} \mathrm{C}$ to $4.8^{\circ} \mathrm{C}$.

Transient Systems Simulation Software (TRNSYS) by Ahmed et al., [9] estimated the thermal performance of the EAHE system for different shapes and work conditions in the UK. The model used to EAHX using UK climatic and the soil parameters. Use of passive and low energy strategies for cooling and heating of buildings. Their result showed major enhancement in potential and internal thermal conditions the to decrease use of the energy intensive conservative cooling systems.

Choi et al., [10] studied the geothermal of heat pump for heating of poultry house. In comparison with the conventional heater, the of heat pump rises the body weight gain, rate mortality is not affected, the internal air quality is enhanced, the fuel consumption was cheap, and the electricity consumption is improved. fact, the geothermal of heat pump allows the lesser cost of heating, developed the production performance with decline amount of the gas's discharges.

Also, they used MATLAB software with CFD modeling, H Hammadi and Mohammed [11] studied to investigate the influence of the length pipe, the velocity air, and pipe diameter on the performance of the air thermal heat exchanger system in Basrah, used earth to the air heat exchanger (EAHE) collected with Solar chimney (SC). The diameter, depth, length the air velocity of the pipe is respectively $(0.2 \mathrm{~m}, 4 \mathrm{~m}, 70 \mathrm{~m}, 2 \mathrm{~m} / \mathrm{s})$, material of the pipe is PVC as shown Figure 1 . the dimension of the room $4 \mathrm{~m} \times 4 \mathrm{~m} \times 3.12 \mathrm{~m}$. The results have shown that the potential of the Earth Pipe is providing lower outlet temperature of the air inside the room. They discover that the temperature at the outlet from the buried pipe declines with increasing the length of pipe, declining pipe diameter, declining mass flow rates of flowing air in the pipe and increasing depths up to $4 \mathrm{~m}$.

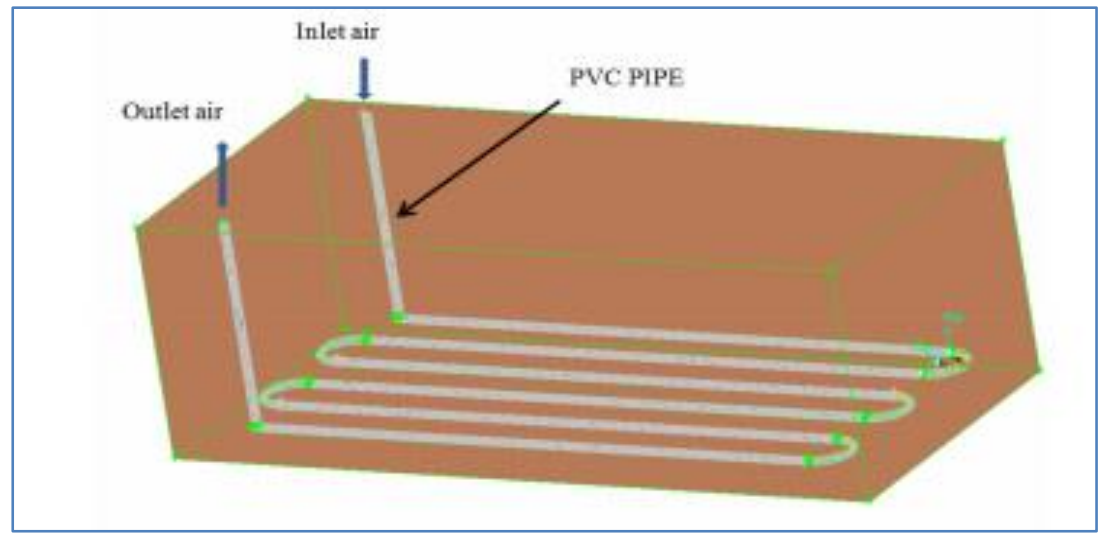

Fig. 1. The Earth-tube-air heat exchanger system

Benhammou and Draoui [12] investigated experimental and theoretical influence of dynamical and geometrical parameters on the thermal performance of EAHEs the thermal performance of (EAHE) for summer cooling in the Algerian Sahara. The buried pipe has a length, an internal diameter and a thickness of $5 \mathrm{~mm}$. Their Results presented that the air outlet temperature declines with increasing the length of pipe, however, it increases with increasing the velocity of air and pipe cross sections, both experimental and theoretical facts of other investigators showed a good arrangement. Also, experimental that the performance coefficient declined fast with increasing the velocity of air.

Laknizi et al., [13] designed and modelled an earth-air heat exchanger for a typical poultry house to estimate the potential of cooling and heating. The air temperature inside poultry houses located 
in Morocco $30^{\circ} \mathrm{C}$ to $33^{\circ} \mathrm{C}$, the dimension of the EAHE was fixed to be $D=0.2 \mathrm{~m}$ and $\mathrm{L}=30 \mathrm{~m}, 2 \mathrm{~m}$ is the buried depth. The PVC and polypropylene (PP) are pipe material used. The system was modelled in ANSYS and CFD software. Through the results they discovered that the outlet temperature is $15^{\circ} \mathrm{C}$ for the cooling mode in summer and heating mode in winter was $21.8^{\circ} \mathrm{C}$.

Hasan and Noori [14] studied numerically the effect of wall thickness and pipe material on the overall performance of EAHE. The dimension of pipe buried at depth pipe with inner diameter and length $(3 \mathrm{~m}, 0.1016 \mathrm{~m}, 50 \mathrm{~m})$ in the south of Iraq in Nasiriyah city. The materials that use made pipe are PVC and steel, and three thicknesses (2, 3 and 6$)$ of the system. The results showed the more suitable to use is PVC pipe because it is non-corrosive and less cost compared with a steel pipe. The influence of wall thickness on the overall performance is less and can be neglected, the pressure drops and the exit air temperature for the two materials increased with increasing the velocity of air.

Hasan and Noori [15] presented numerically the influence of the parameters (inlet condition, pipe diameter, pipe length, and exit condition) on the overall performance of the earth air heat exchanger (E AHE) system. The EAHE pipe has four diameters of $(0.058 \mathrm{~m}, 0.0782 \mathrm{~m}, 0.1036 \mathrm{~m}$, and $0.1544 \mathrm{~m})$. A $50 \mathrm{~m}$ pipe length with depth of $3 \mathrm{~m}$ of the EAHE system buried under earth surface for winter and summer seasons in southern Iraq for Nasiriyah city. They simulated result presented that the EAHE systems with the pipe of diameter $(0.1544 \mathrm{~m})$ have the finest values of overall performance. While, the diameter of the pipe more suitable is 2 in from the thermal performance point of view.

This type of earth air heat exchanger is not widely used in the cooling of poultry houses and some influencing factors have been studied and its use for cooling poultry houses has been studied. As poultry houses are usually located in the remote region and need electrical energy and there are some regions where there is no electrical power, so the ground energy can be used with this type of exchangers to cool it down and this is what distinguishes the research.

\section{Problem Description}

The model used for studying in this research is a 3D earth air heat exchanger system buried under the earth surface by internal pipe diameter of $(0.1016 \mathrm{~m})$ and lengths of $355 \mathrm{~m}, 370 \mathrm{~m}, 385 \mathrm{~m}, 395$ $\mathrm{m}$ and $410 \mathrm{~m}$. Figure 2 displays the pipe of EAHEs with the thickness of disturbed soil. PVC is the material that was certain for study.

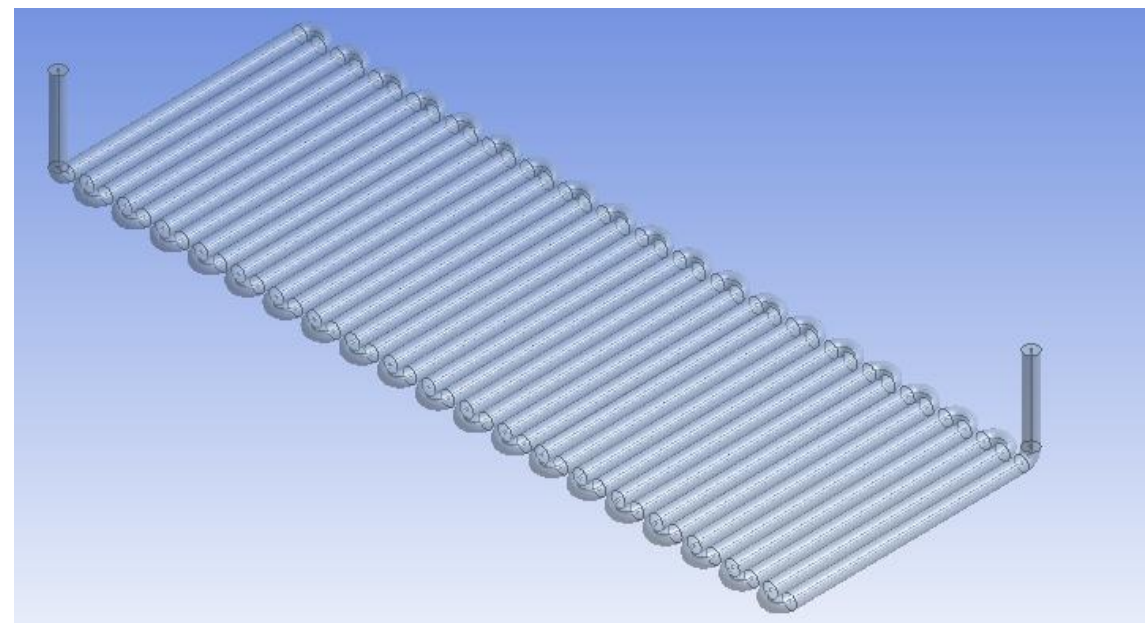

Fig. 2. Schematic of EAHE system the model studied 


\subsection{Disturbed Soil}

The layer of soil nearby the surface of earth air heat exchanger pipes is influenced by heat transfer and this the soil named thermally disturbed soil Figure 3. There is no law for calculating the thickness of disturbed soil, several academics proposed that the thickness of the disturbed soil equaled to the pipe diameter, four times of pipe radius, twice of pipe diameter, and 10 times of the pipe diameter, also several studies establish out that the influence of disturbed soil on the performance of earth air heat exchanger systems can be reduced by running the system in winter and summer seasons [1620]. The thickness of disturbed soil is equivalent to four times of pipe diameter in this research as studied by Chel and Tiwari [7].

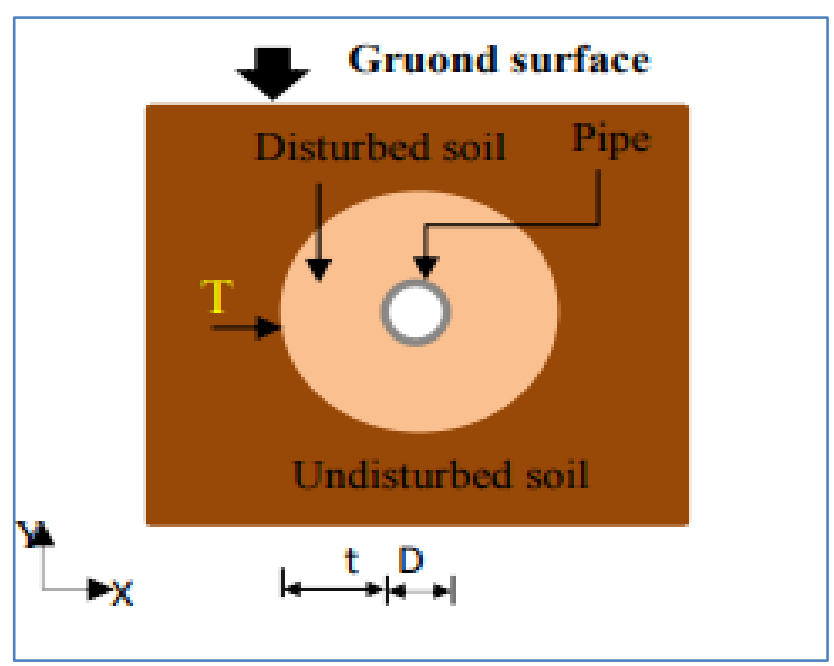

Fig. 3. Cross sections of EAHE pipe

\section{Mathematical Model}

\subsection{Governing Equations}

The next equations of heat transfer and fluid flow are used in this study $[21,27]$.

The equation of continuity

$\frac{\partial u}{\partial x}+\frac{\partial v}{\partial y}+\frac{\partial w}{\partial z}=0$

Momentum equations

$u \frac{\partial u}{\partial x}+v \frac{\partial u}{\partial y}+w \frac{\partial u}{\partial z}=-\frac{1}{\rho} \frac{\partial p}{\partial x}+\mu \rho\left(\frac{\partial 2 u}{\partial x 2}+\frac{\partial 2 u}{\partial y 2}+\frac{\partial 2 u}{\partial z 2}\right)$

$u \frac{\partial v}{\partial x}+v \frac{\partial v}{\partial y}+w \frac{\partial v}{\partial z}=-\frac{1}{\rho} \frac{\partial P}{\partial y}+\mu \rho \mu \rho\left(\frac{\partial 2 v}{\partial x 2}+\frac{\partial 2 v}{\partial y 2}+\frac{\partial 2 v}{\partial z 2}\right)$

$u \frac{\partial w}{\partial x}+v \frac{\partial w}{\partial y}+w \frac{\partial w}{\partial z}=-\frac{1}{\rho} \frac{\partial P}{\partial z}+\mu \rho\left(\frac{\partial 2 w}{\partial x 2}+\frac{\partial 2 w}{\partial y 2}+\frac{\partial 2 w}{\partial z 2}\right)$ 
Energy equation

$\rho C p\left(u \frac{\partial T}{\partial x}+v \frac{\partial T}{\partial y}+w \frac{\partial T}{\partial z}\right)=k\left(\frac{\partial 2 T}{\partial x 2}+\frac{\partial 2 T}{\partial y 2}+\frac{\partial 2 T}{\partial z 2}\right)$

For defining the overall performance factor of EAHE systems $\left(n^{*}\right)$, which symbolizes the relation of heat transfer rate between soil and air to pumping power requested [22-24].

$\eta=\frac{Q}{p \cdot p}$

where

$Q=m c p \Delta T$

where P.P is the pumping power and calculated from

$p \cdot p=\Delta \mathrm{p} . \mathrm{V}$

To find the type of the flow from the following equation

$R e=\frac{\rho u_{i} D_{h}}{\mu}$

where

$D_{h}$ is the hydraulic diameter.

To calculate the pressure, drop from the following equation

$\Delta \mathrm{p}=p_{\text {out }}-p_{\text {in }}$

The physical properties of the air and thermal, soil and pipe material (PVC) is assumed constant and their values are known in the Table $1[15,16,28]$.

Table 1

Properties of used materials

\begin{tabular}{llll}
\hline Material & $\mathrm{P}\left(\mathrm{kg} / \mathrm{m}^{3}\right)$ & $C p(\mathrm{~J} / \mathrm{kg} \mathrm{K})$ & $\mathrm{K}(\mathrm{W} / \mathrm{m} \mathrm{K})$ \\
\hline Air & 1.225 & 1006.5 & 0.0242 \\
Soil & 2050 & 1840 & 0.52 \\
PVC & 1380 & 900 & 0.16 \\
\hline
\end{tabular}

\subsection{Boundary Conditions}

On the inside segment of the earth air heat exchanger pipe the inlet dry bulb temperature (Tin) is constant and the velocity of air constant was used with turbulent flow and subsonic. The values of dry bulb temperature which used for example the boundary conditions were certain for winter and summer seasons according to the south of Iraq in the Nasiriya city. The pressure was taken at an exit equivalent to atmospheric pressure. At walls, the horizontal section of earth air heat exchanger pipes is in the thermal exchange with the thickness of disturbed soil as in Figure 1. At the outside superficial 
of disturbed soil with distance from pipe wall $(t=0.2032 \mathrm{~m})$, the temperature of the soil is constant and equivalent to $\left(\mathrm{T}\right.$ soil $=26.3^{\circ} \mathrm{C}$ ) which agree to the temperature of undisturbed soil which was measured an experimental by the depth of $3 \mathrm{~m}$ in Iraq of the south [25]. The vertical segment is assumed thermally isolated since the rises in air temperature for each of them (inside and exit) are equivalent and its assumed isolated to simplify the numerical solution thus cancel both others [26].

\subsection{Modeling the Poultry House}

After studying and specifying the appropriate design parameters for establish and work the EAHE, a poultry house with selected area (length $=90 \mathrm{~m}$, width $=11 \mathrm{~m}$, side height $=2.7 \mathrm{~m}$, middle height $=$ $4 \mathrm{~m}$ ) and plan is selected to illustrates the potential saving in the consumed energy for cooling and heating of this selected poultry house when it is coupled with EAHE system. Atypical poultry house model has been chosen as a case study with area and plan as commonly used in Iraq of (31.7 $\mathrm{N}^{\circ}$ Latitude and $45.8 \mathrm{E}^{\circ}$ Longitude). The case study consists of a house with floor area of (990 $\mathrm{m}^{2}$ ) and plan as showing in Figure 4. The overall heat transfer coefficient of the walls is $\left(U=2.356 \mathrm{w} / \mathrm{m}^{2} . \mathrm{k}\right)$ and the roof of poultry house no roof insulation $\left(U=1.209 \mathrm{w} / \mathrm{m}^{2} \cdot \mathrm{k}\right)$ and the area of roof $\left(1994.3 \mathrm{~m}^{2}\right)$. The infiltration airflow rate is assumed to be constant and equal to ten air change per hour. the energy of poultry house (11880), 20 ventilations from the back side of the poultry house (diameter $120 \mathrm{~cm}$ ), 2 ventilations from the side of the poultry house (diameter $70 \mathrm{~cm}$ ).

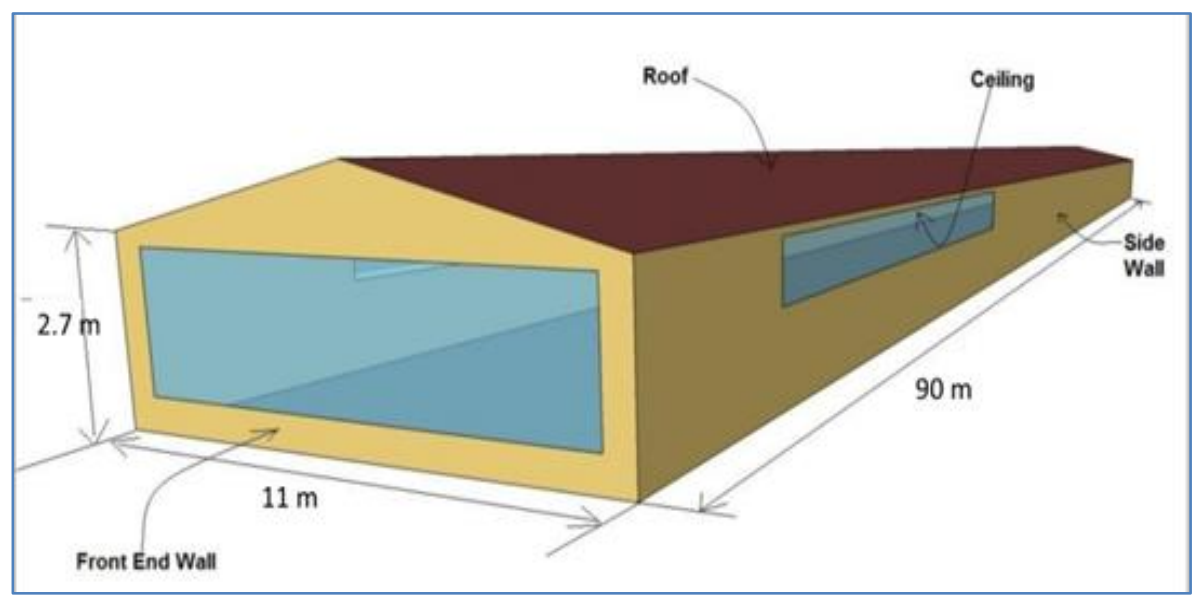

Fig. 4. Modeled poultry House Geometry

\section{Assumption of Flow}

The assumptions were made through the building of the mathematical model [19]

(i) Steady state \& turbulent flow.

(ii) velocity of the Inlet of flow is uniform and constant.

(iii) The physical properties of the soil are constant.

(iv) The fluid is incompressible with properties. 


\section{Numerical Solution}

The governing equations are numerical solved by using the finite volume technique. The flow is improving and the computational fluid dynamics modelling (CFD) are used to solve 3D Navier stock equations and the 3D continuity. To predict the turbulence inlet the pipe, a simple $k-\varepsilon$ model with natural wall handling is certain as energy equation and turbulent classic is furthermore solved as the computations involved the transfer of heat. The values of air flow physiognomies can be found from computational fluid dynamics modelling by a great number of points in the earth to air heat exchanger systems. In the form of a numerical grid, these points are normally linked together. To find the quality of the advanced CFD model with the great precise solution the test of grid independent was conducted, since a mesh attempt has been made, also the results of the solution were unchanged. The computer that used in a numerical solution has a specification (Core i5) and has a RAM (8GB) and the execution time of runtime up to thirty minutes.

Table 2 consist of many refinements of meshes, in this table illustrations the different meshes certain and during this table, it can be seen understood that, after attempts of mesh the solution of independent of mesh size after the third mesh. Hence, for calculating later solutions the fourth mesh will be used. ANSYS software 19.2 has been used to work the numerical solution

Table 2

Grid independent check

\begin{tabular}{ll}
\hline Element size & Outlet temperature $(\mathrm{K})$ \\
\hline mesh1(732546) & 299.6732 \\
mesh2(1317730) & 299.5664 \\
mesh3(1994518) & 299.436 \\
mesh4(2536351) & 299.4 \\
\hline
\end{tabular}

\section{Results and Discussions}

\subsection{Validation}

This model is validated with a numerically model obtained in the study by Hasan and Noori [15]. To check the validity of the made numerically model a verification was built by solving the model numerically. An earth air heat exchanger system involves a pipe with $50 \mathrm{~m}$ length, $0.1016 \mathrm{~m}$ diameter, so PVC is a material made up. The air temperature of outlet EAHE systems with three the air velocity $(1,3,5,7$, and $9 \mathrm{~m} / \mathrm{s})$ were measured with an inside air temperature of $50^{\circ} \mathrm{C}$ and disturbed soil temperature of $26.3^{\circ} \mathrm{C}$ [15].

Figure 5 displays the relationship between the simulation results of the present model with the simulations results of the study by Hasan and Noori [15] for the variant of the air temperature of the outlet with the air velocity. From this figure, it can be noted that, the agreement between the simulations results of the present model with the simulation results of the study by Hasan and Noori [15] is suitable with an average error of $3 \%$. Then, the present numerical model is dependable and can be used with suitable precision. 


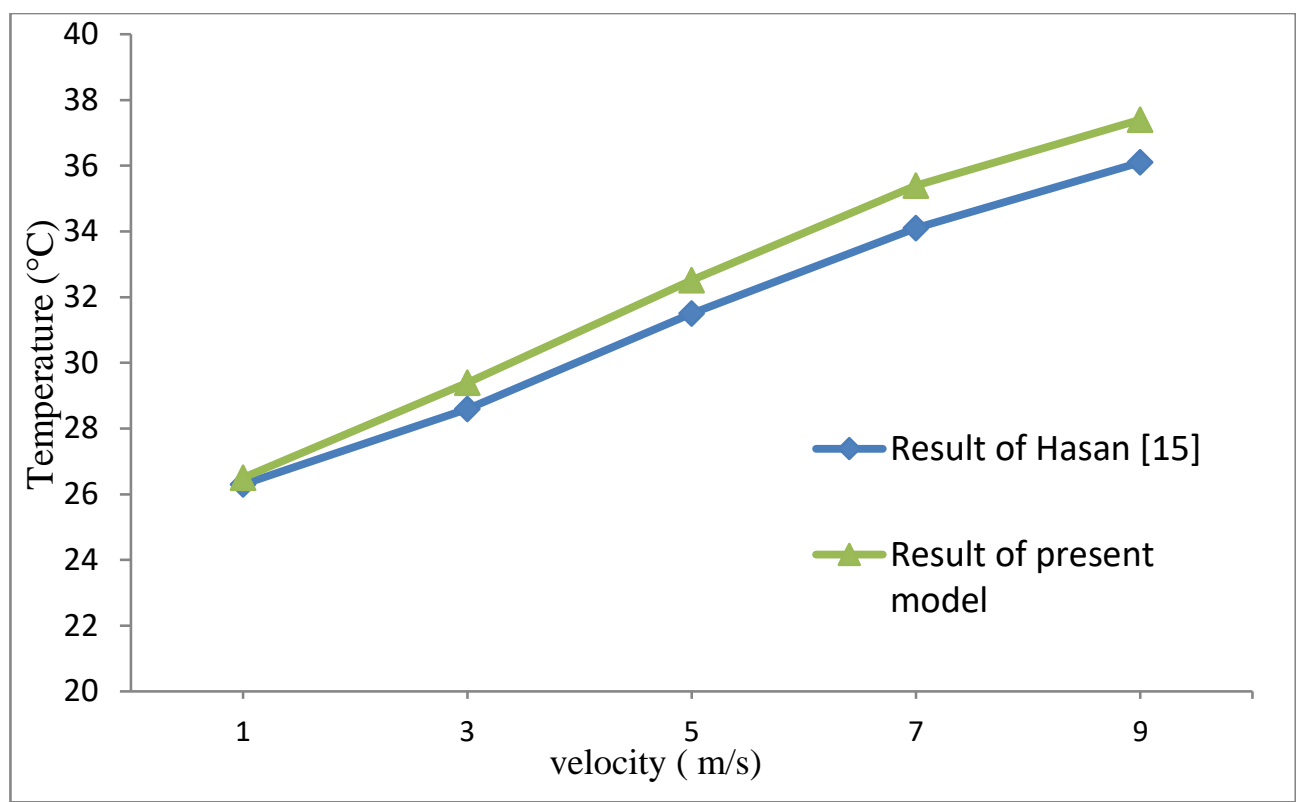

Fig. 5. Variation of outlet temperature with velocity for Earth air heat exchanger as a comparison between the result of the present model for air [15]

\subsection{Result}

Figure 6 shows the variation of heat released by a heat exchanger with an outlet temperature of Earth air heat exchanger of air for all studied mass flow rates of EAHE pipe. From this figure, it can be seen that the released by heat exchanger increased with increasing the outlet temperature due to an increase in the amount of temperature entering the space, and for increasing the mass flow rate that is lead to increase in released by the heat exchanger.

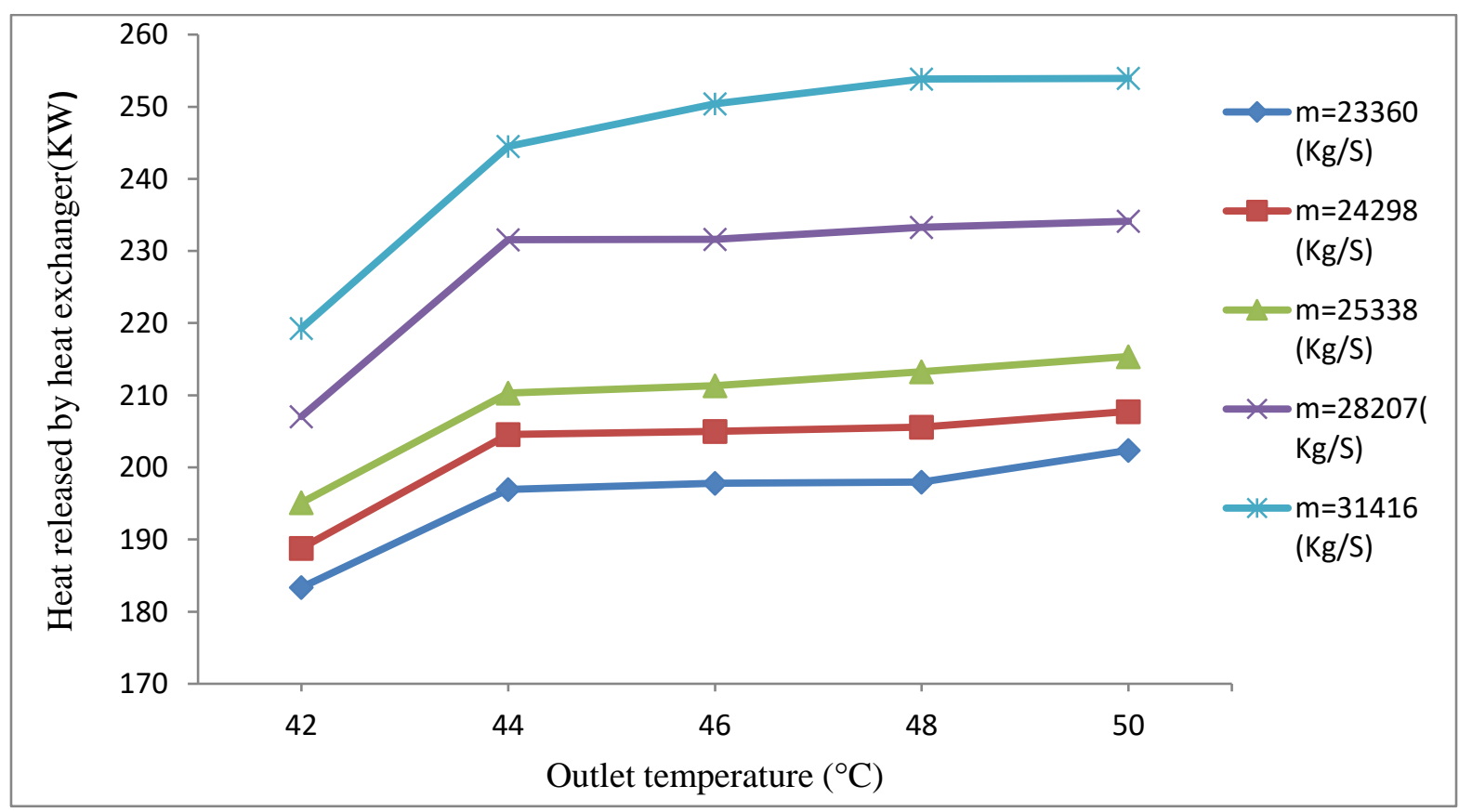

Fig. 6. Variation of heat released by a heat exchanger with an outlet temperature of Earth air heat exchanger of air for all studied mass flow rate of EAHE pipe 
Figure 7 display the variation of heat released by a heat exchanger with mass flow rates of Earth air heat exchanger of air for all studied lengths of EAHE pipe. From the figure, it can be shown that the heat released by the heat exchanger increased by increasing mass flow rate due to increasing the amount of heat that can be absorbed for all lengths of pipe, with increasing lengths of pipe lead to increase with a velocity which enhance from mass flow rate, Also, This, in turn, leads to an increase in the required cooling load. Moreover, the more length gives high required heat released by the heat exchanger.

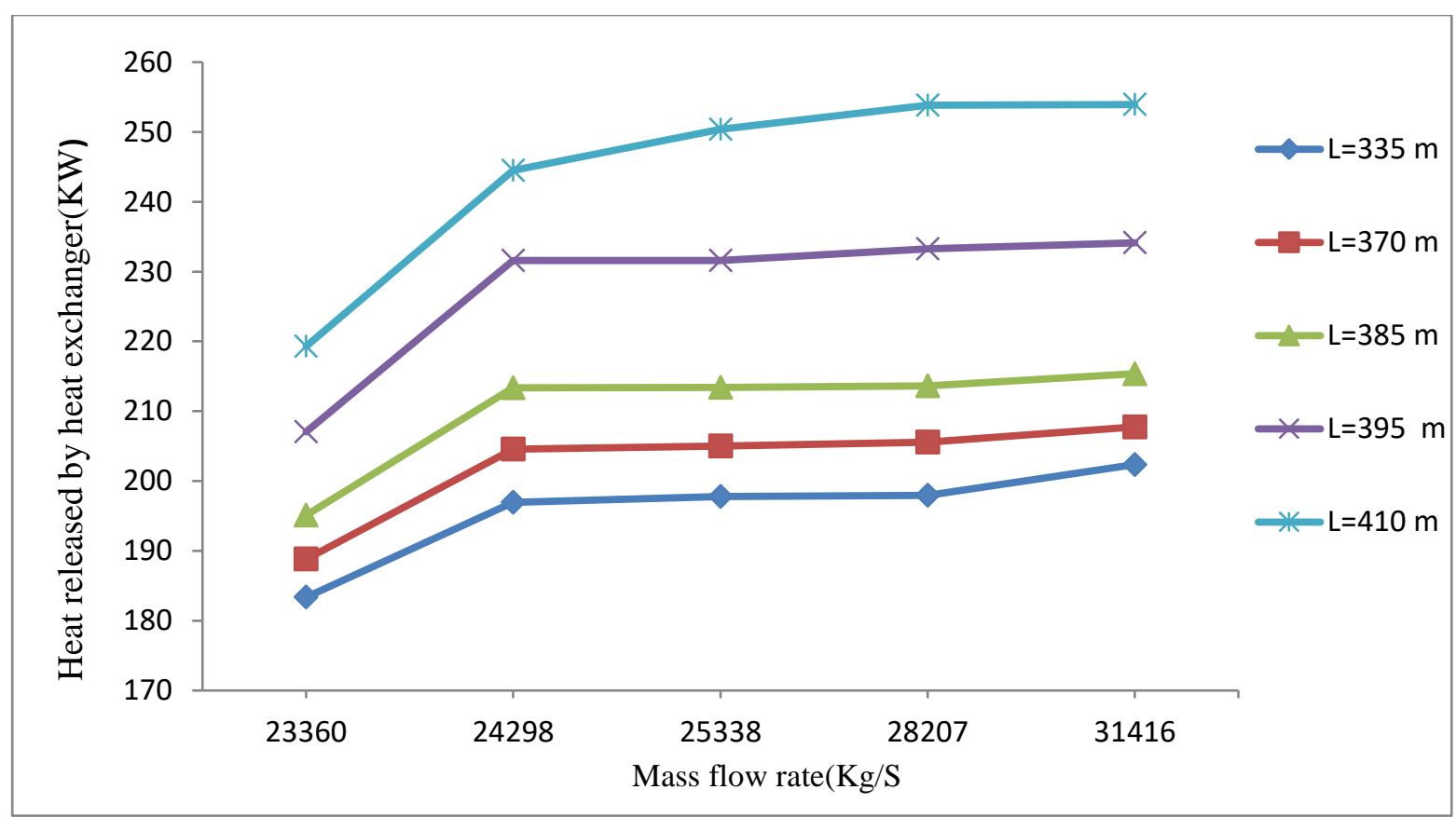

Fig. 7. Variation of heat released by a heat exchanger with mass flow rates of Earth air heat exchanger of air for all studied lengths of EAHE pipe

Figure 8 shows the variation of heat released by a heat exchanger with mass flow rates of Earth to air heat exchanger of the air for all studied outlet temperature of the EAHE pipe. The shape can be observed that the increased in heat released by a heat exchanger with a mass flow rate due to the increase in outlet temperature of air with different velocity for all pipe. Furthermore, the high outlet temperature of air gives large heat released by the heat exchanger.

Figure 9 presents the difference of pressure drop with mass flow rates of Earth- air heat exchanger of the air for all studied lengths of EAHE pipe. From this figure, it can saw that pressure drop increased with increase mass flow rates due to the increase of velocity of the air, because to increase of lengths of pipe. So, the large length of pipe needs to high velocity which leads to an increase of pressure drop.

Figure 10 shows the variation of pressure drop with mass flow rates of Earth- air heat exchanger of the air for all studied outlet temperature of the EAHE pipe. From this figure, it can be seen that pressure drop increase with increasing mass flow rate cause increase of cooling load with an increase in outlet temperature led to increase by pressure drop. Whereas, the high outlet temperature of air gives a high pressure drop. 


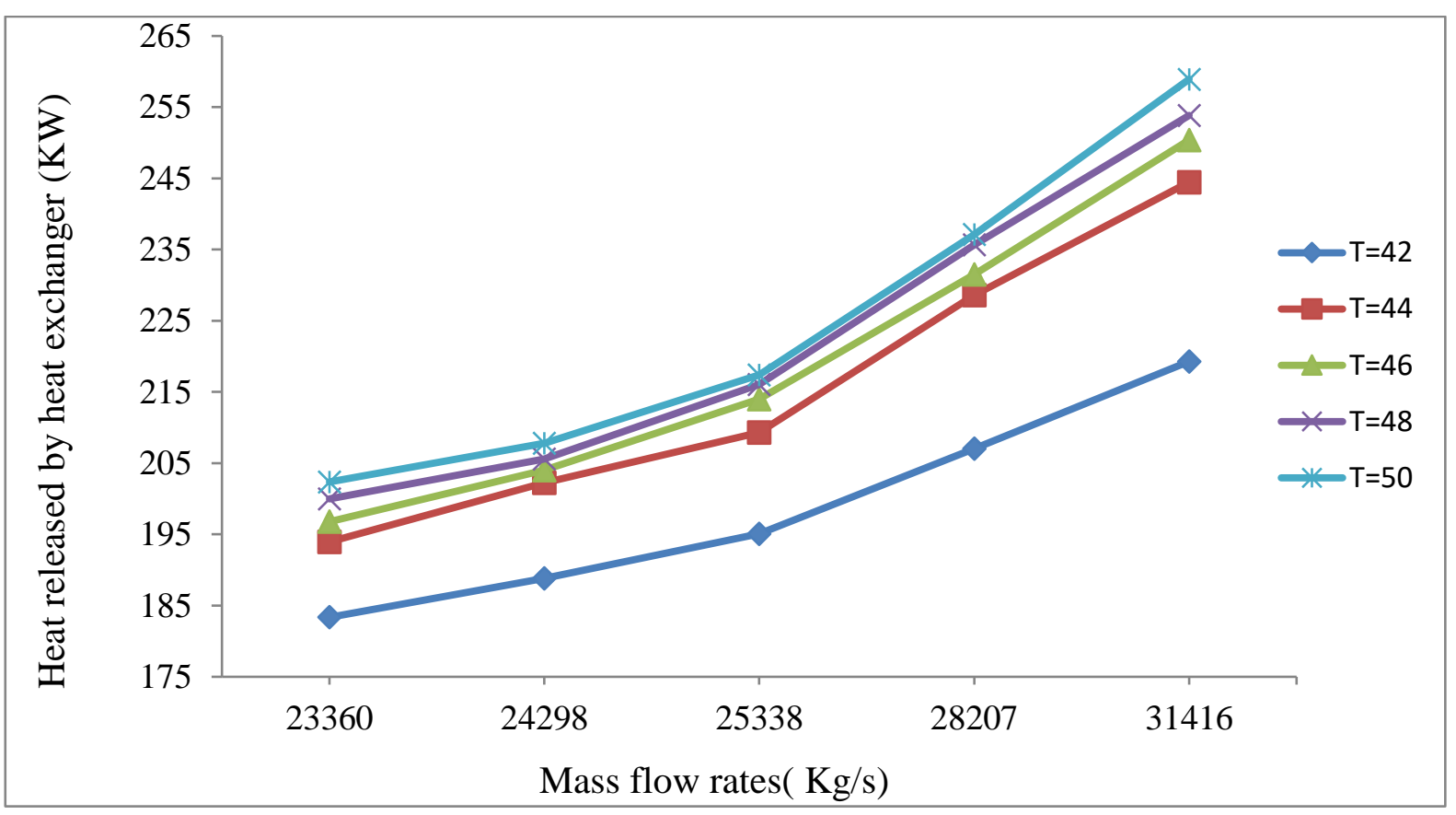

Fig. 8. Variation of heat released by heat exchanger with mass flow rate of Earth - air heat exchanger of air for all studied outlet temperature of EAHE pipe

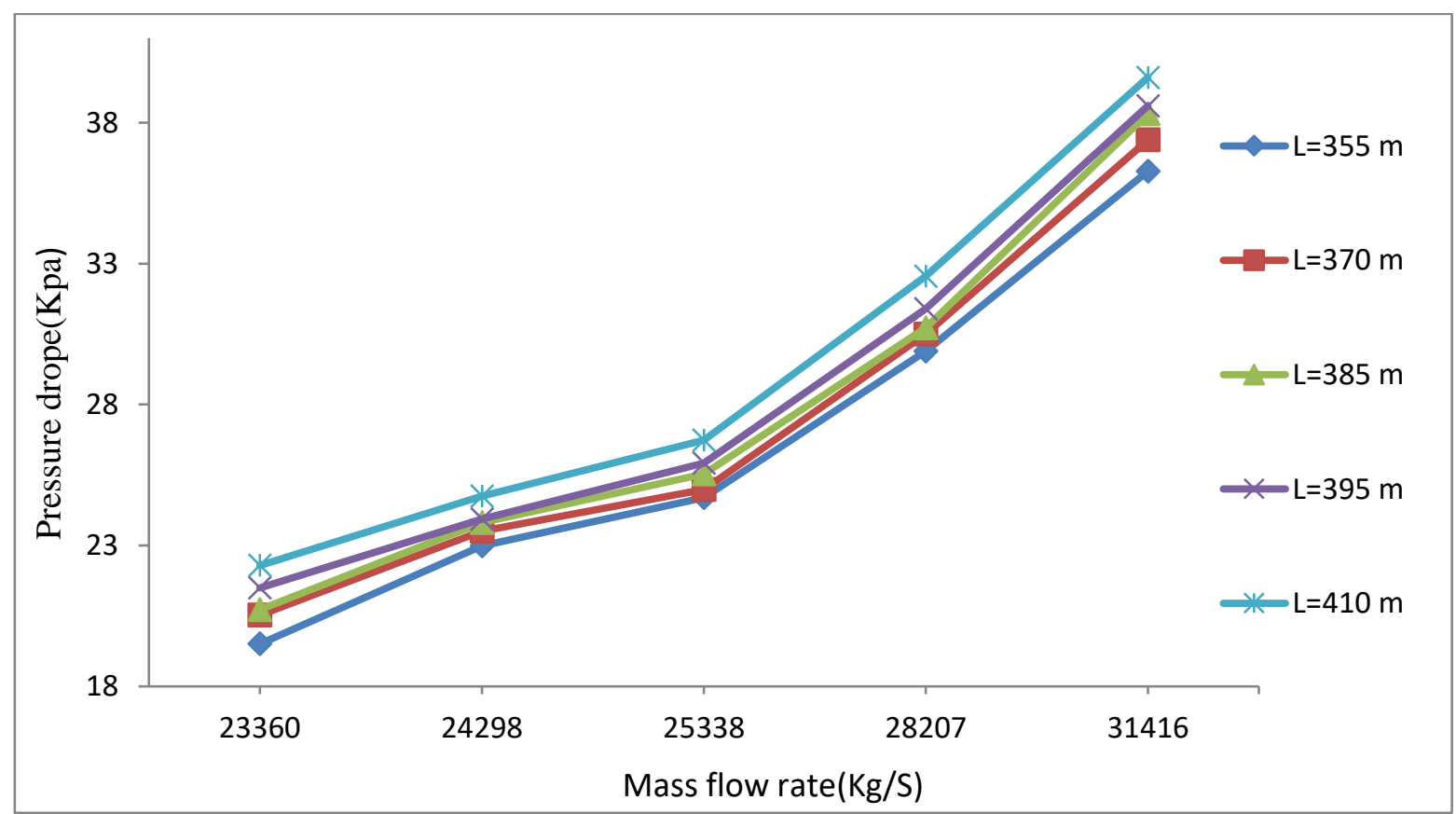

Fig. 9. Variation of pressure drop with mass flow rates of Earth air heat exchanger of air for all studied lengths of EAHE pipe 


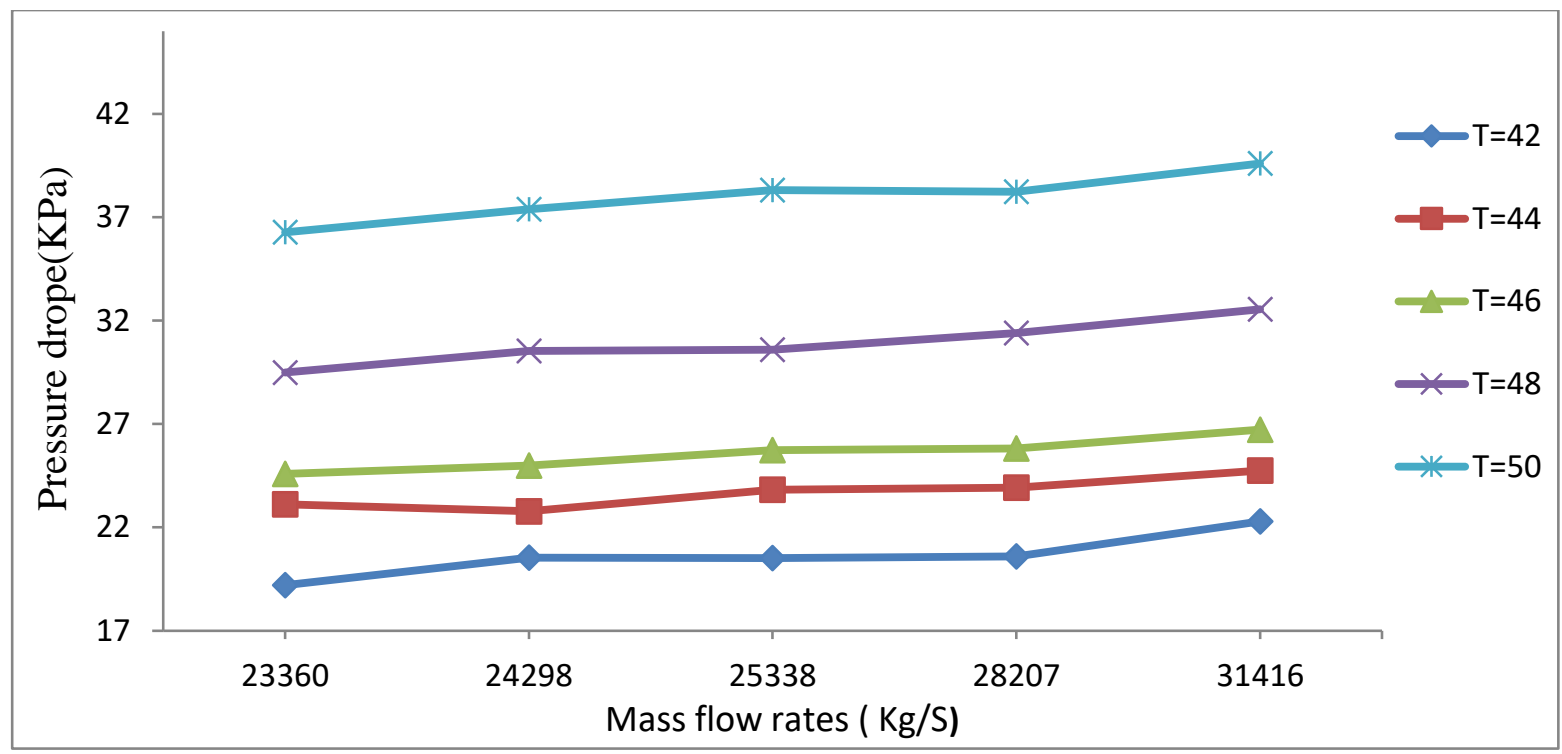

Fig. 10. Variation of pressure drops with mass flow rates of Earth air heat exchanger of air for all studied outlet temperature of EAHE pipe

Figure 11 obtains the variation of pumping power with mass flow rates of Earth air heat exchanger of air for all studied outlet temperature of the EAHE pipe. This figure explained the increase in the pumping power with increasing mass flow rates due to the increase outlet temperature of the air. Also, due to rise pressure drop with mass flow rate that increases from pumping power $p . p=\Delta \mathrm{p}$. V.

Figure 12 explains the variation of pumping power with mass flow rates of Earth to air heat exchanger of the air for all studied lengths of EAHE pipe. It can be noted from the figure that pumping power increased with increasing the mass flow rates due to increasing lengths of pipe, whereas increase lengths of pipe lead to increase pumping power, and length gives high pumping power.

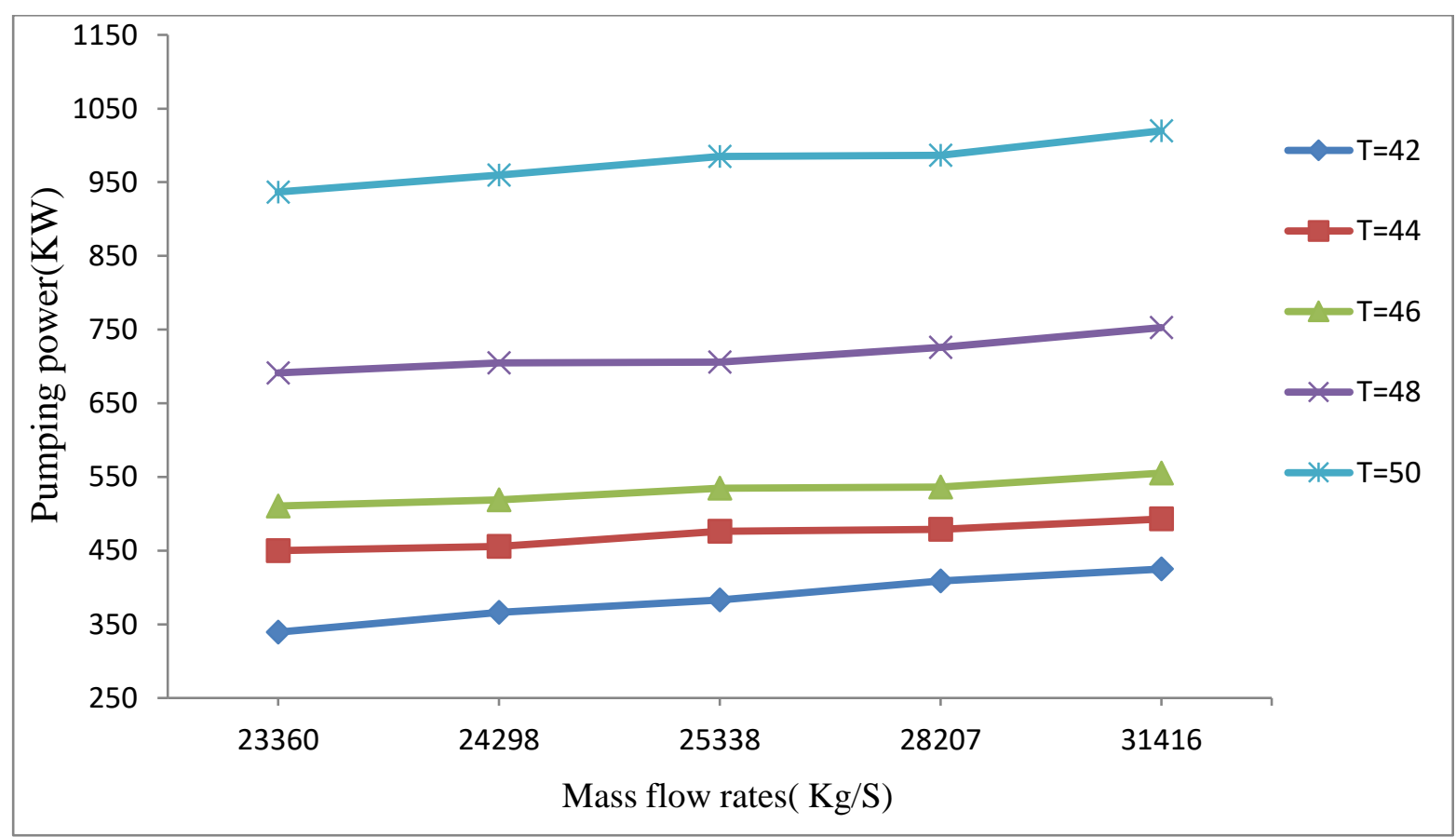

Fig. 11. Variation of pumping power with mass flow rates of Earth-air heat exchanger of air for all studied outlet temperature of EAHE pipe 


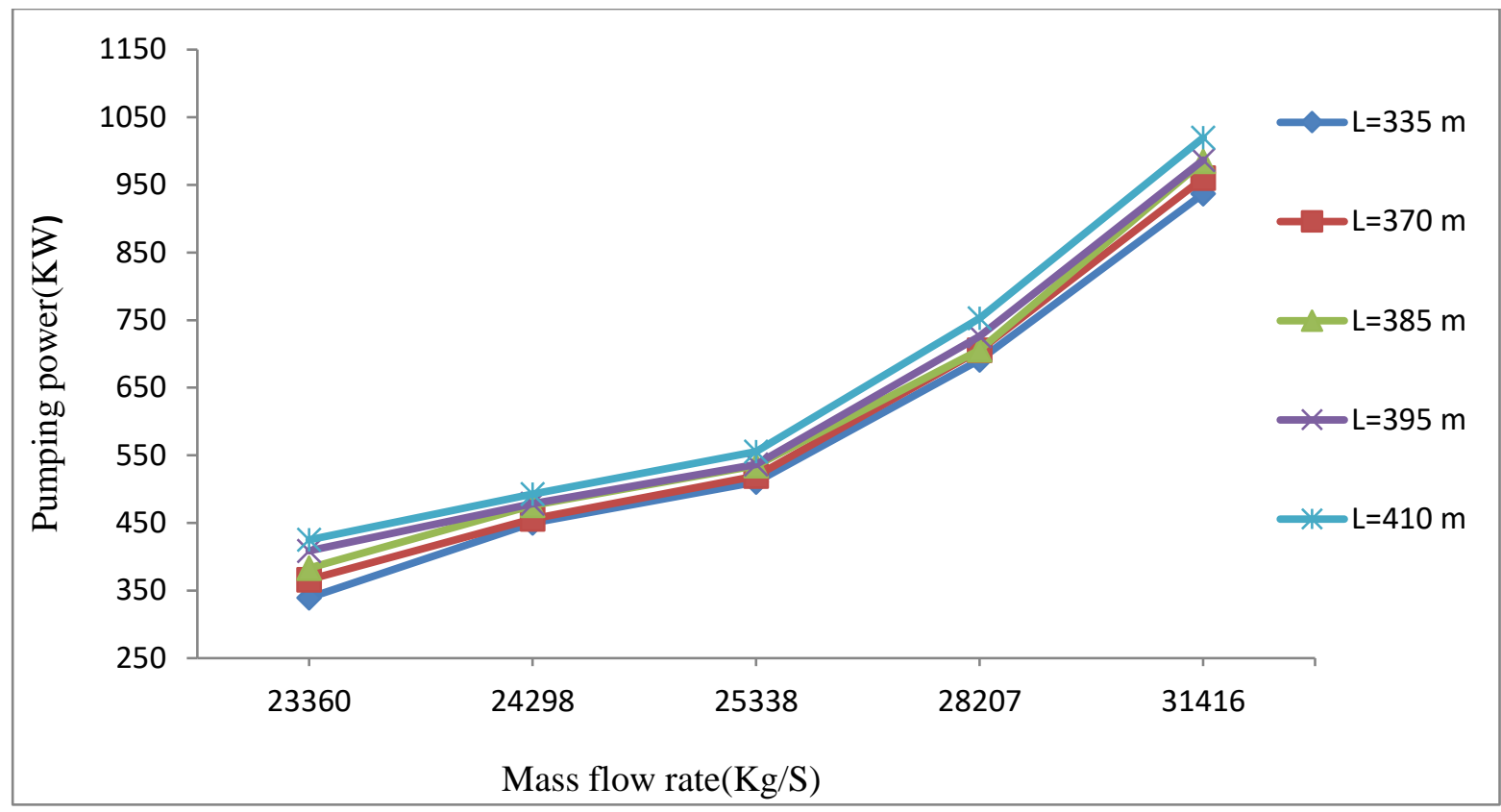

Fig. 12. Variation of pumping power with mass flow rates of Earth air heat exchanger of air for all studied lengths of EAHE pipe

Figure 13 expressions the variation of overall performance factor with mass flow rates of Earth air heat exchanger of the air for all studied outlet temperature of EAHE pipe. This figure explained decrease the performance factor with increase mass flow rates due to high pumping power and due to increasing outlet temperature of air lead to increase pumping power which reduction performance factor, $\eta=Q / p$. $p$.Also, the high outlet temperature of air gives less performance factor due to rise pressure drop.

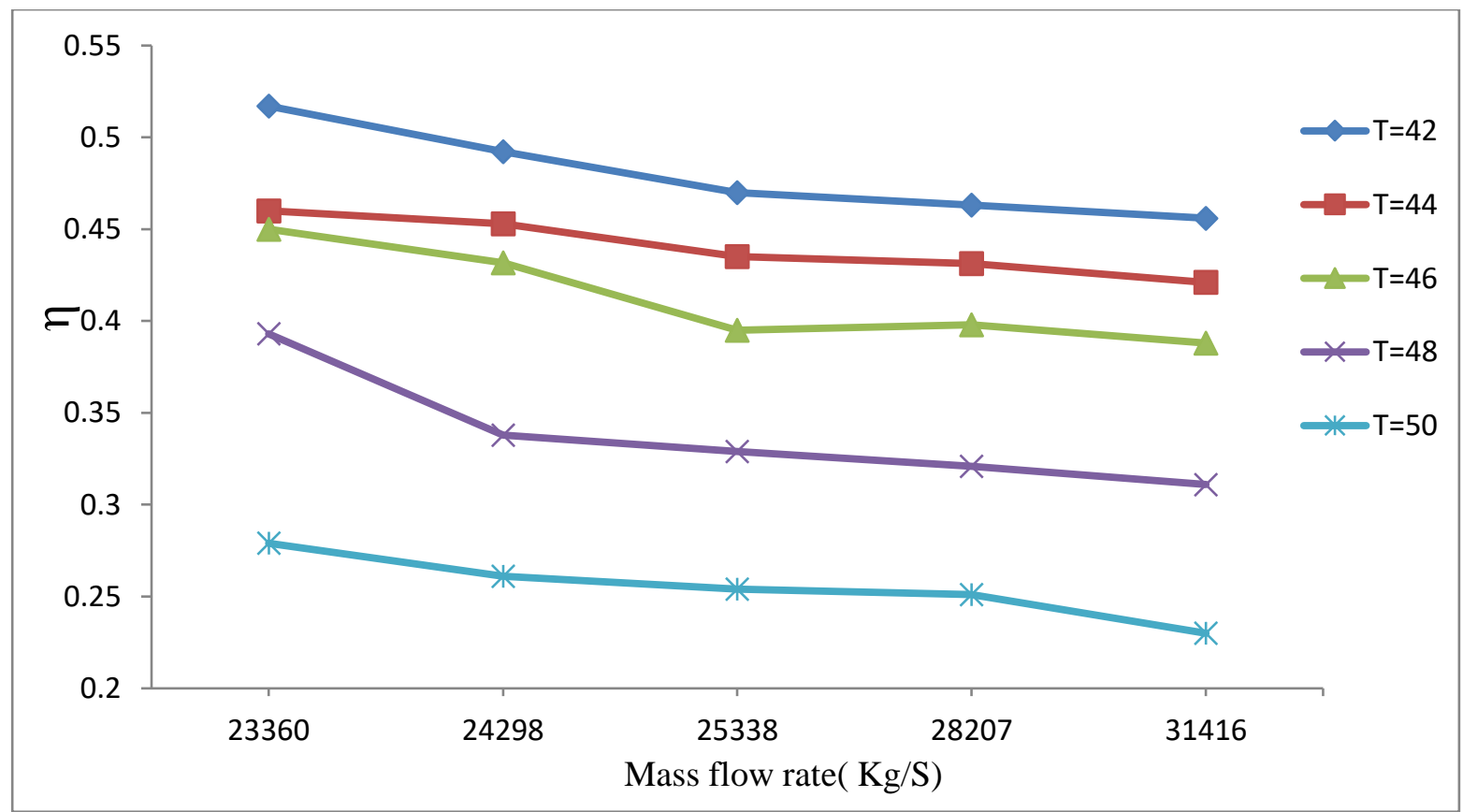

Fig. 13. Variation of overall performance factor with the mass flow rate of Earth-air heat exchanger of air for all studied outlet temperature of EAHE pipe 
Figure 14 explains the variation of overall performance factor with mass flow rates of Earth-toair heat exchanger of air for all studied lengths of EAHE pipe. From this figure, it can be noted that decline in the performance factor with increase mass flow rates due to increased pumping power and because of increase in the lengths of pipe. whereas, the high length gives less performance factor due to increase pumping power.

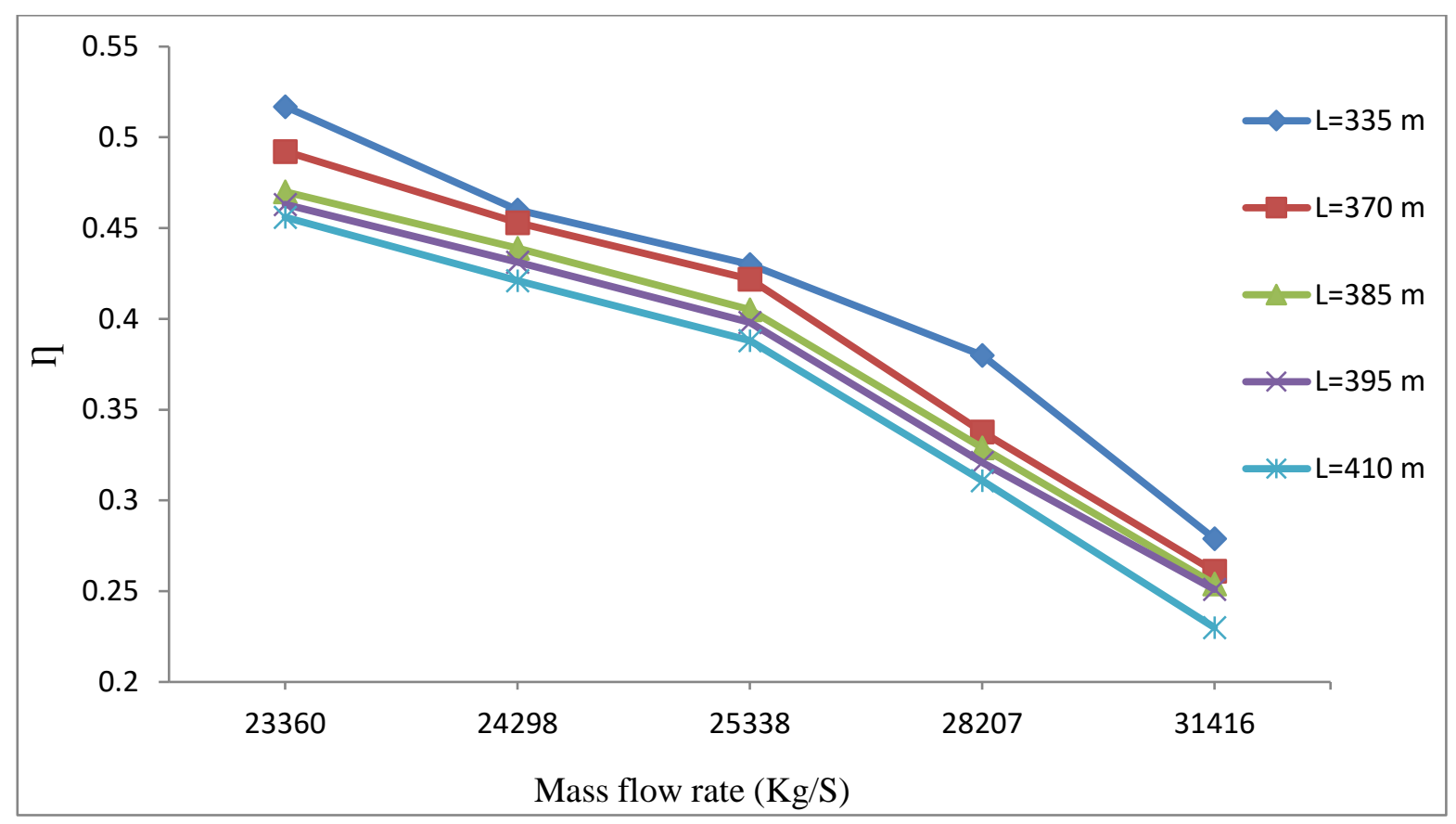

Fig. 14. Variation of overall performance factor by mass flow rates of Earth air heat exchanger of air for all studied lengths of EAHE pipe

Figure 15 shows the variation of cooling load with the length of pipe of Earth air heat exchanger of air for all studied lengths of EAHE pipe. From this shape it can be noted that heat released by heat exchanger increase with increasing lengths of the pipe due to increase mass flow rate and an increase in outlet temperature. Also, due to transfer of temperature between the pipe and soil.

Figure 16 presents the variation of pressure drop with lengths of pipe of Earth air heat exchanger of air for all studied outlet temperature of EAHE pipe. From this figure, it can be seen pressure drop increase with the increasing length of the pipe because of increase outlet temperature of air lead to an increase in heat released by a heat exchanger. So, the high length gives an increase in pressure drop at high temperature.

Figure 17 shows the variation of supply temperature from the pipe of EAHE with outlet temperature of air for all studied lengths of pipe of EAHE pipe. From this figure, it can be noted that the supply temperature increased with increasing the outlet temperature of air due to increase in mass flow rates of air inlet to the pipe and due to declining air retention, the pipe with increasing mass flow rates. Also, the supply temperature declined with increase the lengths of pipe, whereas that the short length of pipe gives high supply temperature inlet to the space due to the pressure drop is less than others. 


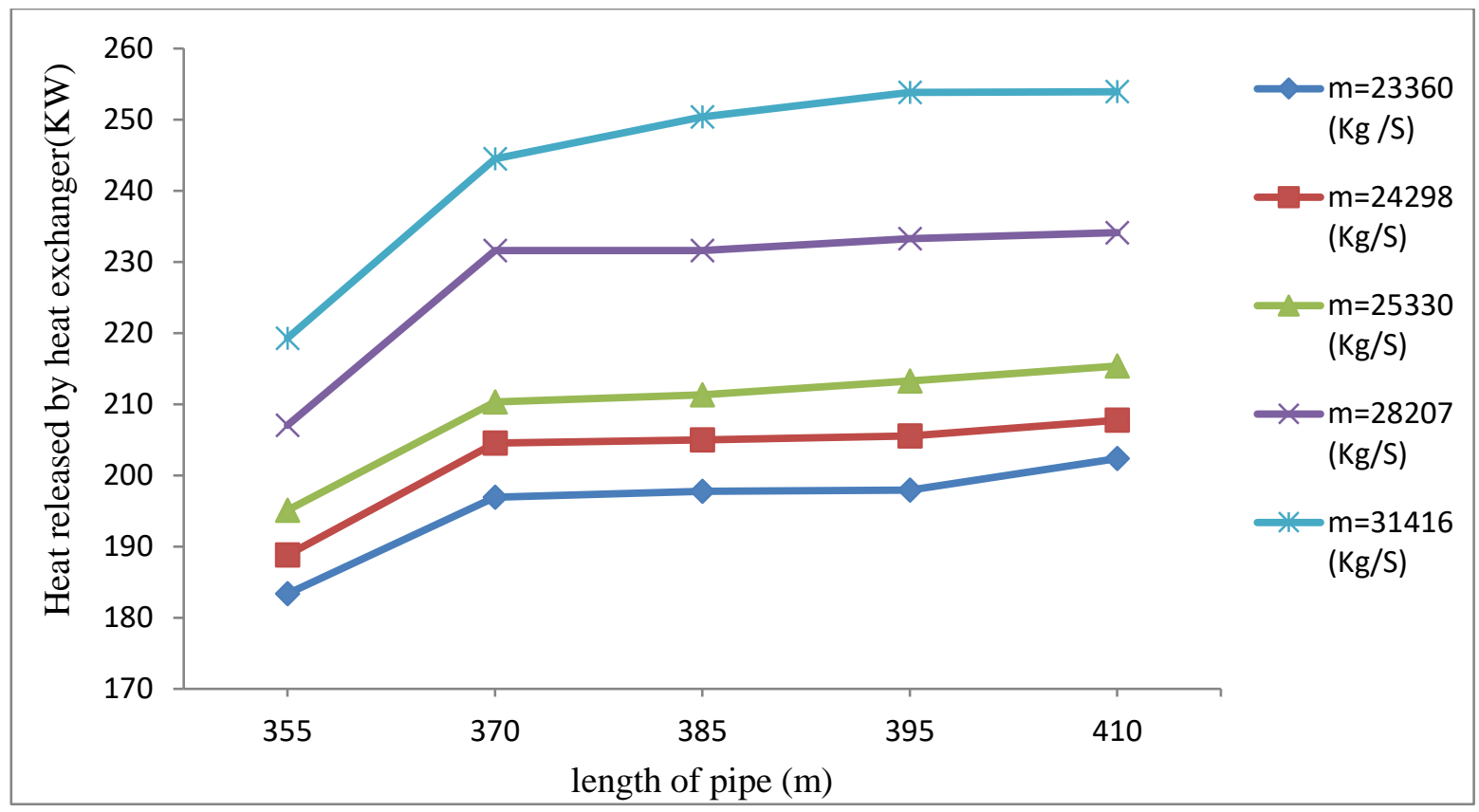

Fig. 15. Variation of heat released by heat exchanger with length of pipe of Earth air heat exchanger of air for all studied mass flow rate of EAHE pipe

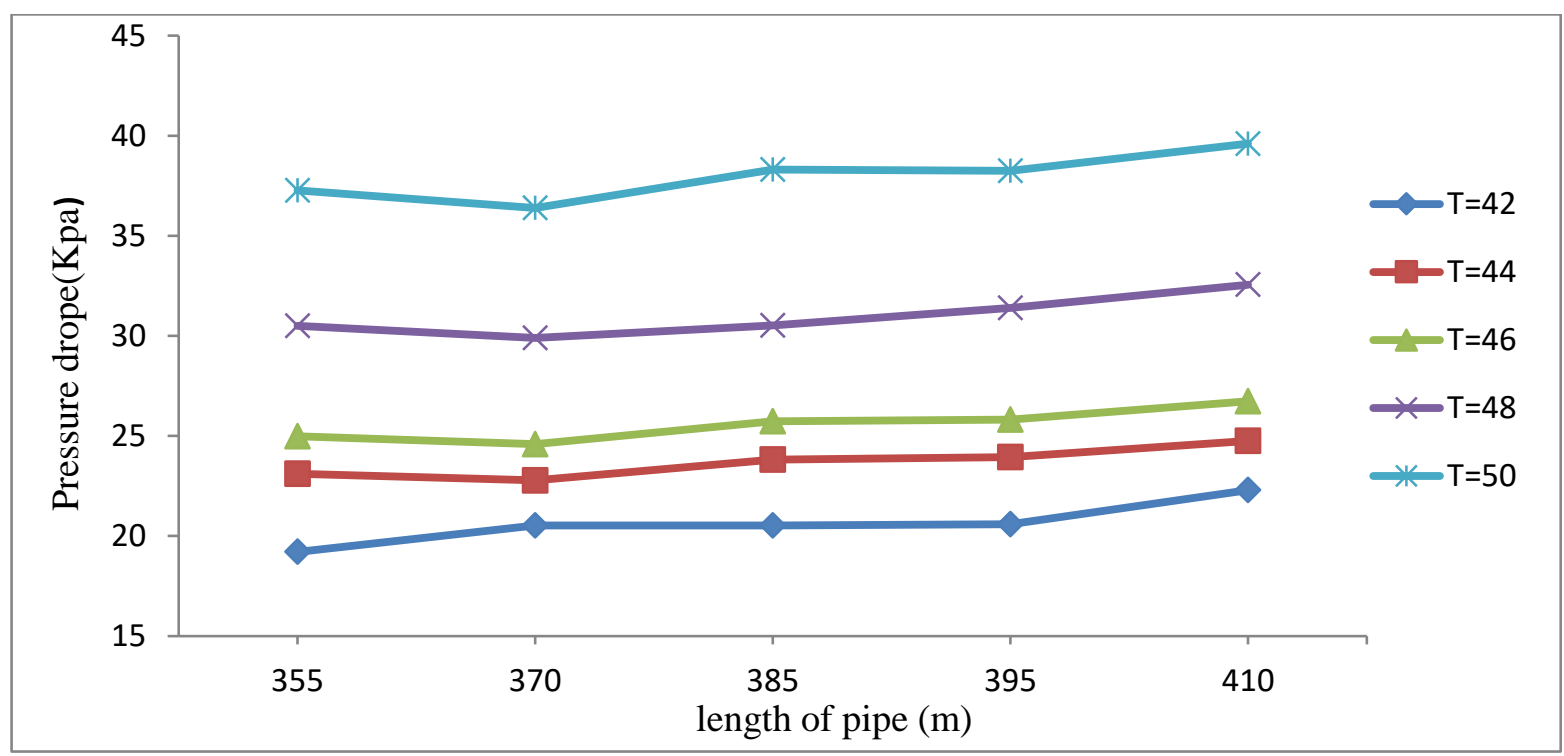

Fig. 16. Variation of pressure drop with lengths of pipe of Earth air heat exchanger of air for all studied outlet temperature of EAHE pipe 


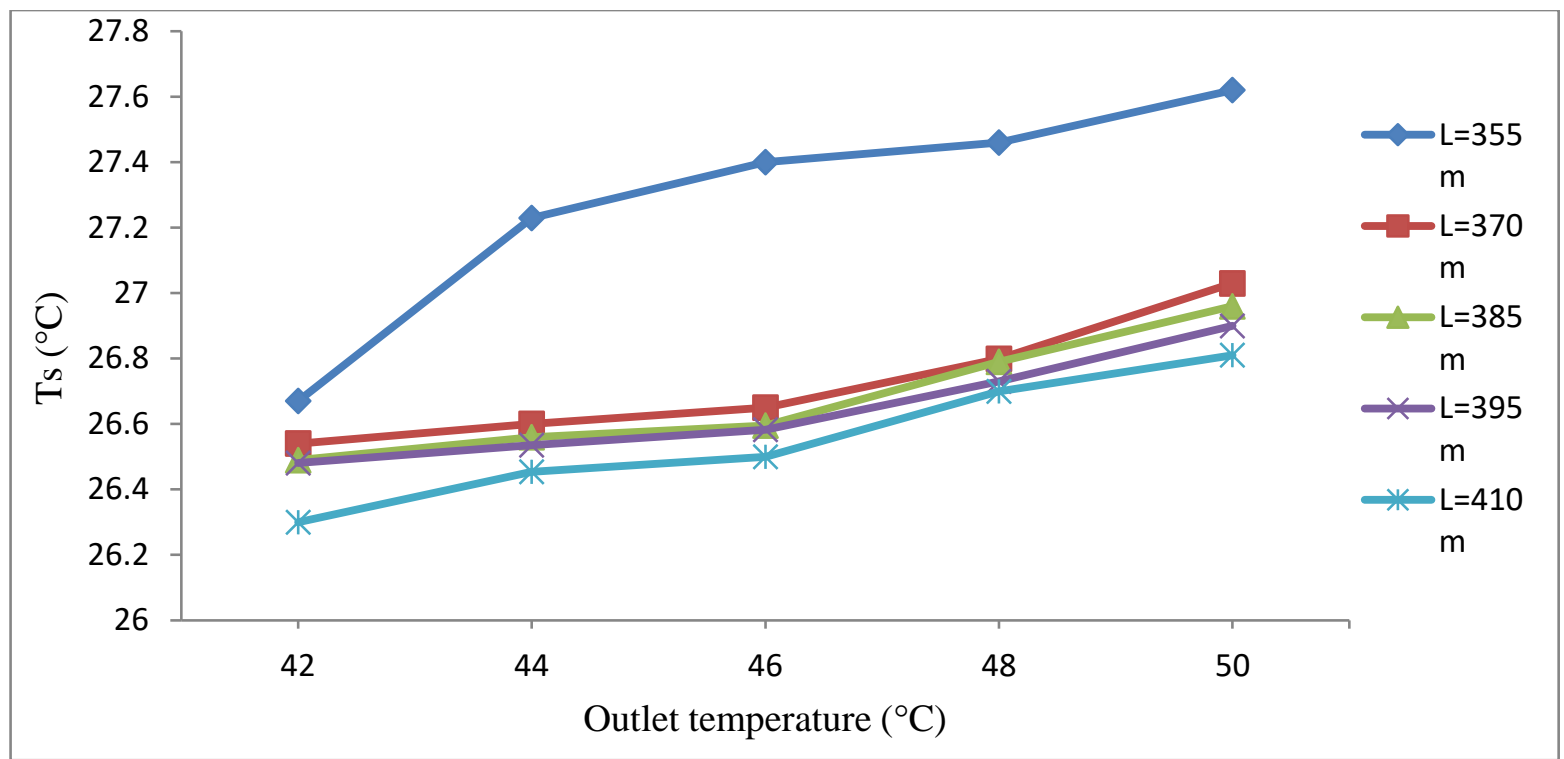

Fig. 17. Variation of supply temperature from the pipe of EAHE with outlet temperature of air for all studied lengths of pipe of EAHE pipe

\section{Conclusion}

A numerical model is designed simulated and tested in this study to show the influence of pipe length and mass flow rate on the overall of performance of Earth air heat exchanger system. The model is tested under climatic conditions of in Nasiriya city in the south of Iraq using of poultry houses as a study case.

The simulated results of presented framework, the following conclusions can be showed; The required cooling load increases with the increase in the outlet air temperature. Whereas, a high temperature at outlet gives the required cooling load large and with an increase in the mass flow rate of air. Pressure drop is increased with increasing mass flow rate for regardless lengths of pipe, and by increasing the pressure drop is increased. The increase in pipe length decreases the temperature of the inlet air of the poultry house. Pumping power increases with increasing mass flow rate. Also, the increase of pressure drop lead to increase pumping power. The increase in pumping power led to reduction in overall performance factor. The overall performance factor of the EAHEs is improved when the system is working as the cooling system especially with short lengths of pipe.

\section{References}

[1] Sodha, M. S., R. L. Sawhney, B. C. Jayashankar, and A. K. Sharma. "Effect of different earth surface treatments on the thermal performance of a room coupled to an earth-air tunnel." International Journal of Energy Research 14, no. 3 (1990): 337-354. https://doi.org/10.1002/er.4440140309

[2] Sharan, Girja, and Ratan Jadhav. Soil Temperatures Regime at Ahmedabad. Indian Institute of Management, 2002.

[3] Al-Ajmi, F., D. L. Loveday, and Victor lan Hanby. "The cooling potential of earth-air heat exchangers for domestic buildings in a desert climate." Building and Environment 41, no. 3 (2006): $235-244$. https://doi.org/10.1016/j.buildenv.2005.01.027

[4] Okonkwo, W. I., and C. O. Akubuo. "Trombe wall system for poultry brooding." International Journal of Poultry Science 6, no. 2 (2007): 125-130. https://doi.org/10.3923/ijps.2007.125.130

[5] Ahachad, M., R. Belarbi, N. Bouaziz, and F. Allard. "Poultry housing in the Arab World: applying principles of thermal exchange to improve performance (A case study of Morocco)." Emirates Journal of Food and Agriculture (2008): 60-75. https://doi.org/10.9755/ejfa.v20i1.5181

[6] Ghosal, M. K., Sujata Nayak, and G. N. Tiwari. "Modeling and experimental study for winter performance of an earth to air heat exchanger: An alternative energy source for greenhouse." Agricultural Engineering International: CIGR Journal (2008). 
[7] Chel, Arvind, and G. N. Tiwari. "Performance evaluation and life cycle cost analysis of earth to air heat exchanger integrated with adobe building for New Delhi composite climate." Energy and Buildings 41, no. 1 (2009): 56-66. https://doi.org/10.1016/j.enbuild.2008.07.006

[8] Bansal, Vikas, Rohit Misra, Ghanshyam Das Agrawal, and Jyotirmay Mathur. "Performance analysis of earth-pipeair heat exchanger for winter heating." Energy and Buildings 41, no. 11 (2009): 1151-1154. https://doi.org/10.1016/i.enbuild.2009.05.010

[9] Ahmed, Abdullahi, Kenneth Ip, Andrew Miller, and Kassim Gidado. "Thermal performance of earth-air heat exchanger for reducing cooling energy demand of office buildings in the United Kingdom." In 11th Conference of International Building Performance Simulation Association, vol. 2009, pp. 2228-2235. 2009.

[10] Choi, H. C., H. M. Salim, N. Akter, J. C. Na, H. K. Kang, M. J. Kim, D. W. Kim, H. T. Bang, H. S. Chae, and O. S. Suh. "Effect of heating system using a geothermal heat pump on the production performance and housing environment of broiler chickens." Poultry Science 91, no. 2 (2012): 275-281. https://doi.org/10.3382/ps.2011-01666

[11] H Hammadi, Salman, and Alaa Hlaichi Mohammed. "Application of earth tube heat exchanger and solar chimney for natural cooling system in Basrah City." Basrah Journal for Engineering Science 14, no. 2 (2014): 23-32.

[12] Benhammou, Mohammed, and Belkacem Draoui. "Parametric study on thermal performance of earth-to-air heat exchanger used for cooling of buildings." Renewable and Sustainable Energy Reviews 44 (2015): 348-355. https://doi.org/10.1016/i.rser.2014.12.030

[13] Laknizi, Azzeddine, Anas ElMaakoul, Abdellatif Ben Abdellah, Mouhsine Bouya, Said Dhimdi, and Saadeddine Said. "Evaluation of earth-air heat exchanger for cooling and heating a poultry house: case study in Morocco." In 2015 3rd International Renewable and Sustainable Energy Conference (IRSEC), pp. 1-5. IEEE, 2015. https://doi.org/10.1109/IRSEC.2015.7455040

[14] Hasan, Mushtaq Ismael, and Sajad Waleed Noori. "Numerical investigation of Earth to air heat exchanger for cooling and heating applications." In Proc. Of the 3rd Int. Sci. Conf, vol. 14, p. 15. 2018.

[15] Hasan, Mushtaq I., and Sajad W. Noori. "A study of the potential of using the Earth to air heat exchanger for cooling and heating of residential buildings in Iraq." Heat Transfer-Asian Research 48, no. 8 (2019): 3902-3927. https://doi.org/10.1002/htj.21574

[16] Al-Ajmi, F., D. L. Loveday, and Victor lan Hanby. "The cooling potential of earth-air heat exchangers for domestic buildings in a desert climate." Building and Environment 41, no. 3 (2006): $235-244$. https://doi.org/10.1016/i.buildenv.2005.01.027

[17] Gauthier, Carol, Marcel Lacroix, and Hervé Bernier. "Numerical simulation of soil heat exchanger-storage systems for greenhouses." Solar Energy 60, no. 6 (1997): 333-346. https://doi.org/10.1016/S0038-092X(97)00022-4

[18] Misra, Rohit, and VikasBansal, and Abhishek Agarwal. "Investigation of Thermal Performance of EATHE System under Intermittent Operation: A CFD Approach." International Journal of Engineering Technology, Management and Applied Sciences 4, no. 4 (2016): 340-349.

[19] Niu, Fuxin, Yuebin Yu, Daihong Yu, and Haorong Li. "Heat and mass transfer performance analysis and cooling capacity prediction of earth to air heat exchanger." Applied Energy 137 (2015): $211-221$. https://doi.org/10.1016/j.apenergy.2014.10.008

[20] Mathur, Anuj, Ankit Kumar Surana, and Sanjay Mathur. "Numerical investigation of the performance and soil temperature recovery of an EATHE system under intermittent operations." Renewable Energy 95 (2016): $510-521$. https://doi.org/10.1016/i.renene.2016.04.037

[21] Gan, Guohui. "Simulation of dynamic interactions of the earth-air heat exchanger with soil and atmosphere for preheating of ventilation air." Applied Energy $158 \quad$ (2015): $118-132$. https://doi.org/10.1016/i.apenergy.2015.08.081

[22] Hasan, Mushtaq I., Abdul A. Rageb, M. Yaghoubi, and Homayon Homayoni. "Influence of channel geometry on the performance of a counter flow microchannel heat exchanger." International Journal of Thermal Sciences 48, no. 8 (2009): 1607-1618. https://doi.org/10.1016/j.ijthermalsci.2009.01.004

[23] Hasan, Mushtaq Ismael, Hayder Mohammed Hasan, and Ghassan Adnan Abid. "Study of the axial heat conduction in parallel flow microchannel heat exchanger." Journal of King Saud University-Engineering Sciences 26, no. 2 (2014): 122-131. https://doi.org/10.1016/i.jksues.2012.12.004

[24] Hasan, Mushtaq Ismael. "Influence of wall axial heat conduction on the forced convection heat transfer in rectangular channels." Basrah Journal for Engineering Science 1 (2011): 31-43.

[25] Hasan, Mushtaq I., and Eman Kareem Jabbar. "Fabricating and testing of the ground coupled air conditioner for residential applications in Iraqi weather." Energy $216 \quad$ (2021): 119256. https://doi.org/10.1016/j.energy.2020.119256

[26] Hasan, Mushtaq Ismael, and Sajad Waleed Noori. "Evaluating the influence of some design and environmental parameters on the performance of earth to air heat exchanger." Journal of Engineering and Sustainable Development 22, no. 02 Part-1 (2018): 10-29. https://doi.org/10.31272/jeasd.2018.2.2 
[27] Sakhri, Nasreddine, Younes Menni, and Houari Ameur. "Experimental investigation of the performance of earthto-air heat exchangers in arid environments." Journal of Arid Environments 180 (2020): 104215. https://doi.org/10.1016/j.jaridenv.2020.104215

[28] Sakhri, Nasreddine, Younes Menni, and Houari Ameur. "Effect of the pipe material and burying depth on the thermal efficiency of earth-to-air heat exchangers." Case Studies in Chemical and Environmental Engineering 2 (2020): 100013. https://doi.org/10.1016/i.cscee.2020.100013 